\title{
The Impact of Stigma on the Relation Dynamics of the People of Mental Illness and His Family
}

\author{
Mufliha Fahmi \\ Fakultas Psikologi UGM \\ muflihafahmi@gmail.com
}

\author{
Arindah Arimoerti Dano \\ Fakultas Psikologi UGM \\ arindaharimoerti@gmail.com
}

\begin{abstract}
Mental illness is one of the issues that has been increasingly considered as a serious health problem in Indonesia. The number of mental illness cases in Indonesia is quite high. However, many issues related to mental illness has not been addressed seriously such as low public awareness. This paper is based on the author's experience working as a professional intern in Dr. Radjiman Wediodiningrat Mental Hospital, Malang, East Java working with a schizophrenic patient. Observing the patient and his relation to family, the author found that the family has acted more as stressor than as support system to him. This is one obstacle in overcoming mental illness despite the low public awareness on mental illness. In addition, people with mental illness experience negative stigma in the community which add to problem in treating mental illness. Moreover, low public knowledge about mental illness often lead to delay in giving treatment for people with mental illness. These are among the risk factors that can increase the incidence of mental illness in Indonesia. This paper tries to see alternative strategy that may be applied to address these issues. It is the promotion of mental health literacy intervention which should involve various stakeholders, including government institutions, community leaders, religious leaders, family members and educators.
\end{abstract}

Keyword: Mental illness; mental health literacy; schizophrenia

\section{INTRODUCTION}

Health is "a state of complete physical, mental, and social well-being and not merely the absence of disease or infirmity" (WHO, 1948). It means health is not only based on physical, but including mental and social factors. Good mental health is associated with psychological wellbeing[1]. WHO defines mental health as[2]:

"A state of well-being in which the individual realizes his or her own abilities, can cope with the normal stress of life, can work productively and fruitfully and is able to make a contribution to his or her community."

By WHO definition, we know that mental health is associated with good functioning in social, work, and family activities. Someone who has mental illness often facing functioning problems in social, work, and family activities caused by changes in thinking, emotion, and problem. There are many different symptoms in mental illness, one of them is schizophrenia.

According to WHO, Schizophrenia is the $7^{\text {th }}$ most deadly desease in the world [3]. Its prevalence reaches 25 million people all over the world [4]. In Indonesia itself, the number of people suffering from schizophrenia is 400,000 people. Furthermore, according to [5], every year, the prevalence of schizophrenia keeps increasing.

Schizophrenia is characterized by a fundamental deviation on the minds, perceptions, and inappropriate affect[6]. There are three main symptoms classification for schizophrenia: positive (hallucination and delusion), negative symptoms (withdrawal, avolition, diminished expressed emotion), and disorganized symptoms (poor in paying attention, disorganized speech, incoherence). Impairments resulted from schizophrenia commonly cause people to have difficulties in socialize and perform daily activities. Therefore, schizophrenia is seen as one of the disease that has a big potential to cause disability for the people with shizophrenia[3].

Nevertheless, for the patients, barriers do not only come from the disturbances they experience, but also come from the stigma that develops in society. People with schizophrenia are seen as incompetence individual, crazy, even dangerous and harmful for others. These conditions tend to make the people with schizophrenia been shunned, rejected, or even been physical restraint (pasung) by the family[7].

Some studies are showing there is correlation between stigma and lack of mental health literacy[8]. Lack of mental health literacy lead to high stigma to people with schizophrenia. Mental health literacy is defined as "knowledge and beliefs about mental illnesses which aid their recognition, management, or prevention."[9]. Good mental health literacy may lead to better outcomes for those mental illnesses, either by early help-seeking or by identify early signs of mental illnesses[10].

Negative stigma against people with mental illness does not only affect the people with shizophrenia themselves but also affect their families. The society's bad assumption would indirectly affect the family's assumption and leads them to belief that the patient is a disgrace. Obviously, this would create a sense of shame for the family, tend to isolate themselves from outsiders, and might affect the way of the family treat the sufferer as well. Previous research had discovered if the height of expressed emotion in a family meets negative stigma towards sufferer is commonly founded as one of the trigger that makes the patients relapse[11]. Moreover, it's a bit common to find patients whom being rejected or neglected by their family even if they are under a process of treatment.

This paper is based on the author's experience working as a professional intern in Dr. Radjiman Wediodiningrat Mental Hospital, Malang, East Java, working with a shizophrenic patient who had been hospitalized for at least 6 times. In this article, authors are trying to answer following questions: How is stigma against patient affect his family? 
How is interaction between the patient and family affect his condition? Besides, this article is also trying to discover many possible alternatives in terms of breaking the stigma.

\section{METHODS}

\section{A. Subject}

The main subject of this research is $\mathrm{M}$, a male schizophrenic patient at Dr. Rsdjiman Wediodiningrat Mental Hospital. Besides M, there are 4 other informants who are also interviewed, they are nurse, and patient's family (mother, brother, and his uncle).

\section{B. Procedures}

The data was collected through three methods: observation, interview, and psychological test using Thematic Apperception Test (TAT). Researchers interviewed all informants, while TAT was administered only to M. The procedure of collecting data would be explained further as follows.

a. Observation

Researchers made an intense observation to $\mathrm{M}$ from the beginning of assessment process (the day he was hospitalized) until he was discharged from hospital. Afterwards, the observation continued in home setting through home visit on December $6^{\text {th }}$, 2016, hence we observed the family as well. The observation made on $\mathrm{M}$, both at hospital and home, including observation on physical, environment, and interaction aspects.

b. TAT was administered on December $2^{\text {nd }}, 2016$. Researchers showed 10 main cards with different theme in each card. $\mathrm{M}$ was asked to make a complete story based on what he saw on the card, starting with the opening of the story, the climax, and followed by the end of the story. All of his answer was recorded with a voice recorder and been interpreted afterwards. In this article, only related interpretations are going to be clearly explained.

c. The interview with the mental nurse was made on $5^{\text {th }}$ December 2016. Meanwhile, researchers made the first interview with the patient's family was on $5^{\text {th }}$ December as well. Researcher interviewed his brother when he came to the hospital to pick M up and bring him along to home. Afterwards, on $6^{\text {th }}$ December, researcher visited his home and had the

d. opportunity to interview brother, mother, and his uncle. Researcher used unstructured interview to assess both nurse and the family, and helped by two observers when interviewing the family.

\section{b. Thematic Apperception Test (TAT)}

After all the cards have been administered, and all the answers have been recorded, researcher can continue to

\section{Data Analysis}

This research uses qualitative approach $h$ with themat ic analyses for analizing the data [12]. Meanwhile, TAT is analyzed by using clinical interpretation suggested by [13].

\section{a. Observation}

Researcher used participational observation to gather information, as well as build trust and rapport, especially to gain better insight about his subjective experience by actively involved in most of his activities. All the information was recorded and separated based on the aspects set before (physical, environment, and interaction). The result of the observation is provided in Table 1.

TABLE 1

OBSERVATION'S RESULTS

\begin{tabular}{|c|c|c|c|c|}
\hline & Physical & Environment & Interaction & Symptoms \\
\hline $\begin{array}{c}\text { M } \\
\text { (Hospital } \\
\text { setting) }\end{array}$ & $\begin{array}{l}\text { Poor } \\
\text { selfcare }\end{array}$ & $\begin{array}{l}\text { Clean, tidy, } \\
\text { have rules }\end{array}$ & $\begin{array}{l}\text { Sing a lot, } \\
\text { become the } \\
\text { center of } \\
\text { attention, } \\
\text { talkative, } \\
\text { frequently } \\
\text { greet people, } \\
\text { noticed by } \\
\text { most of the } \\
\text { residents in } \\
\text { the hospital. }\end{array}$ & $\begin{array}{l}\text { Regression. } \\
\text { Delussion. } \\
\text { Quite stable }\end{array}$ \\
\hline $\begin{array}{c}\text { M } \\
\text { (Home } \\
\text { Setting) }\end{array}$ & $\begin{array}{l}\text { Poor } \\
\text { Selfcare }\end{array}$ & $\begin{array}{l}\text { The house is } \\
\text { clean, tidy, } \\
\text { well arranged, } \\
\text { good air } \\
\text { circulation, but } \\
\text { the } \\
\text { patient's } \\
\text { bedroom has } \\
\text { limited source } \\
\text { of air and } \\
\text { sunlight as the } \\
\text { only window } \\
\text { is blocked } \\
\text { using bamboo }\end{array}$ & $\begin{array}{l}\text { Greet many } \\
\text { people, } \\
\text { actively ask } \\
\text { people to talk } \\
\text { with him. } \\
\text { Frequently } \\
\text { yelled by his } \\
\text { brother and } \\
\text { his uncle. } \\
\text { Seems quite } \\
\text { afraid of his } \\
\text { brother and } \\
\text { uncle. }\end{array}$ & $\begin{array}{l}\text { Easy to be } \\
\text { mad on } \\
\text { anyone } \\
\text { surround } \\
\text { him, more } \\
\text { talkative, } \\
\text { sing more. }\end{array}$ \\
\hline Family & - & - & $\begin{array}{l}\text { Brother } \\
\text { rejects to } \\
\text { meet the } \\
\text { patient, } \\
\text { brother and } \\
\text { uncle tend to } \\
\text { abuse him } \\
\text { verbally } \\
\text { (cursing using } \\
\text { "stupid" } \\
\text { frequently) } \\
\text { and neglect } \\
\text { him, and } \\
\text { criticize on } \\
\text { almost } \\
\text { everything he } \\
\text { does or says. }\end{array}$ & - \\
\hline
\end{tabular}

the interpretation. The process of interpretation is started with making the verbatim, and arrange them based on the order of the cards given. Afterwards, the story in each card is analyzed by dividing the whole story into three categories: descriptive theme, interpretative theme, and diagnostic theme. Subsequently, researcher would determine any clinical notes founded in every card. In this 
article, only the family related card (card number 3BM, $6 \mathrm{BM}$, and 7GF) would be discussed. This is the final interpretation of card number 3BM, 6BM, and 7GF. "the client seems to have an unfavorable relationship with the family. The family is seen to impose their will and dominant in determining the client's life. Moreover, Client has a tendency to reject coercion, but ultimately chooses to comply in order to maintain harmony and good relations with the surrounding. In addition, client tends to feel unintelligible about their wishes by the family. The client expected that the family can help him get out of the problem at hand, but the family disregarded him and let him fall alone. Conditions like this make the client tend to feel hopeless" (cited from the patient's psychological report, 2016)

\section{c. Interview}

All the interviews conducted are poured into a note as soon as the interview was done. This note and any other documents regarding the interview were organized into a transcript prior to the interpretation process. Considering the patient's condition, recording the interview was not been performed. Afterwards, all the transcripts were grouped into some main themes and were analyzed.

Nurse was interviewed in order to get information regarding his medical record including his diagnoses, medical history, and his medical progress during his current residency. According to nurse, this is his $6^{\text {th }}$ time of hospitalizing in this mental hospital. He always relapses once he had been discharged from hospital and under his family's treatment. This pattern leads the nurse to the assumption that his family's behavior towards the patient is related to his relapses.

The result of categorized theme of the interview shown in Table 2.

TABLE 2

FAMILY'S INTERVIEW RESULTS

\begin{tabular}{|c|c|}
\hline Aspects/Main Theme & Result \\
\hline Attitude & $\begin{array}{l}\text { Feeling of embarrassed to the } \\
\text { neighbors, feel mad anytime he's returning } \\
\text { home, and angry towards most of M's } \\
\text { behaviors }- \text { Reject M presence. One of M's } \\
\text { brother rejects to meet him. } \\
\text { the Demand M to behave similarly to } \\
\text { 'normal people' }\end{array}$ \\
\hline Knowledge & $\begin{array}{l}\text { - Does not know about the } \\
\text { patient's diagnoses } \\
\text { - Family believes if the disturbance was } \\
\text { caused by demon possession } \\
\text { - On the first onset, patient was brought to a } \\
\text { paranormal } \\
\text { - Does not aware of the initial symptoms } \\
\text { - Does not understand about the risk factor of } \\
\text { mental illness } \\
\text { - Does not understand and careless about the } \\
\text { treatment }\end{array}$ \\
\hline
\end{tabular}

\section{RESULTS AND DISCUSSION}

According to the data analysis result, it's known that the family has a very limited knowledge about mental illness. The family did not even know M's medical diagnoses even though he had been having 17 years of schizophrenia and been hospitalized for 6 times. The limitation of the family's knowledge leads them to misunderstanding of the causes of mental illness and ended to seek inappropriate help as the family assume if the disorder is caused by a demon possession.

The limitation of the family's knowledge makes their attitude towards $M$ more to be influenced by the stigma that developed in society. The stigma drives family to treat $\mathrm{M}$ inappropriately without considering his mental condition, either emotionally or behaviorally. On the other hand, the embarrassment that arises from the assumption that mental disorder is a disgrace makes family tend to close themselves from any interventi on. This condition is absolutely worsening the effort to help $\mathrm{M}$, as those negative attitudes and behavior (high expressed emotion) become more unreachable, while family support will always be M's main needs. The verbal violence, anger, and rejection faced by $\mathrm{M}$ anytime he returned to his home are things he never receives in the hospital. This explain why $M$ tends to be more stable under hospital care rather than under family care.

These findings support previous researches which discover that psychiatric patient's relapses are commonly caused by the stigma that developed in society and the degree of family expressed emotion. Furthermore, it seems that the family expressed emotion is affected by the stigma itself and the limitation of the family's knowledge. This is in line with prior finding by [14] whom discover a reciprocal relationship between stigma and expressed emotion. A strong stigma will result a high expressed emotion in the family of psychiatric patient. On the other hand, the high expressed emotion from the family is also described as one of the triggers of the recurrence of psychiatric patients when they are under the family care.

Moreover, a research conducted by [15] explains that there are two alternatives to reduce stigma, they are education about the mental illnesses themselves, and direct interaction with psychiatric patients. Corrigan et.al added that education about mental illnesses would be more effective for youngsters, meanwhile direct interaction works better in older populations. However, findings in this research discover if direct interaction without education would be meaningless. Frequent interaction without sufficient knowledge causes family to behave inappropriately towards the sufferer instead.

According to the result of this research, poor knowledge about mental illness becomes one of the biggest obstacle in treating mental disorder, especially schizophrenia. The low knowledge of mental disorders makes the family's actions against the sufferer would be more being affected by negative stigma based on a misunderstanding of schizophrenia. This makes the family tends to seek improper helps, starting from the onset of symptoms as precautionary until further treatments, including hospitalization. Moreover, this misunderstanding also brings misbehaves and mistreatments up from the 
family against the sufferer which obviously will worsen his condition.

Meanwhile, knowledge limitation about mental health is the first thing which needed to be tackled in preventing as well as treating mental disorder. Mental health education is essential in giving a good understanding about mental disorder. As people's understanding is increasing through adequate education, we are expecting that the bad stigma would be reduced, and their attitude becomes more positive as well. If a family has already had an adequate knowledge and been able to give sufficient support, this would be a promising protective factor for the sufferer which lessen the chance of his relapse. Moreover, through adequate knowledge, the family is expected to be able to recognize the symptoms of mental disorders early and can seek appropriate help.

Nevertheless, it's not only the patients and their family need that mental health education, but other people in wider population is also need this. Aside from reducing the stigma that harm the sufferers and their families, proper education and understanding of mental disorder also improve the rates of early detection as well as treatment of mental disorder, and increase the number of effort to find ealry appropriate help [9]. Proper knowledge and understanding of mental health allow mental disorder being prevented as early as possible.

Education or other efforts to increase people's knowledge and understanding about mental disorders commonly called as mental health literacy interventions. [16] argue that society can be a strategic group in handling mental disorders only if they have good mental health literacy. Mental health literacy interventions with community approaches have been shown remarkable results in increasing awareness and knowledge of mental disorders in various countries [17]. However, researches about mental health literacy intervention in Indonesia are mostly done in school setting [18] Hence, it's necessary to conduct research about mental health literacy intervention in greater setting which involve various stakeholders such as parents, community leaders, religious leaders, as well as local primary health services.

\section{CONCLUSIONS}

The stigma drives family to treat $M$ inappropriately without considering his mental condition, either emotionally or behaviorally. On the other hand, the embarrassment that arises from the assumption that mental disorder is a disgrace makes family tend to close themselves from any intervention. This condition is absolutely worsening the effort to help $\mathrm{M}$, as those negative attitudes and behavior (high expressed emotion) become more unreachable.

Limitation of knowledge and misunderstanding about mental disorder is main issue which needed to be addressed in preventing and treating mental illnesses. Many previous researches prove that mental health literacy intervention is one of the effective strategy to increase the knowledge as well as people's awareness of mental disorders. However, further research is needed to discover the effectiveness of mental health literacy intervention in overcoming the negative stigma against people with mental disorder in Indonesia.

\section{REFERENCES}

[1] B. K., R. F., B. M., A. V., K. I., and L. A., "Relevance of quality of life assessment for multiple sclerosis patients with memory impairment," PLOS ONE, vol. 7, 2012.

[2] "Constitution of WHO: Principles.".

[3] P. K. Kerig, A. A. Ludlow, and C. Wenar, Developmental Psychopathology. New York: McGraw Hill, 2012.

[4] WHO, "Promoting Mental Health: Concepts, Emerging Evidence, Practice."

[5] Andina, "Perlindungan bagi kelompok berisiko gangguan jiwa," Aspirasi, vol. 4, no. 2, pp. 143-154, 2013.

[6] "Riset Kesehatan Dasar 2013." Badan Penelitian dan Pengembangan Kementerian Kesehatan RI.

[7] W. Lestari and Y. F. Wardhani, "Stigma dan penanganan penderita gangguan jiwa berat yang dipasung," Bul. Penelit. Dan Sist. Kesehat., vol. 17, pp. 157-166, 2014.

[8] N. T. O'Keefe, F. S., L. E., K. A., O. E., and C. M., “The relationship between mental health literacy regarding schizophrenia and psychiatric stigma in the Republic of Ireland," J. Ment. Health, vol. 23, no. 2, pp. 100-108, 2016.

[9] J. F., "Mental health literacy: Public knowledge and beliefs about mental disorders," vol. 177, 2000.

[10] K. M., J. A. F., and W. A., "Improving mental health literacy as a strategy to facilitate early intervention for mental disorders," Med. J. Aust., vol. 187, pp. 26-30, 2007.

[11] S. M. Fadli and Mitra, "Pengetahuan dan ekspresi emosi keluarga serta frekuensi kekambuhan penderita skizofrenia," J. Kesehat. Masy. Nas., vol. 7, pp. 466-470, 2013.

[12] V. Braun and V. Clarke, "Using thematic analysis in psychology," Qual. Res. Pyschology, vol. 3, pp. 77-101, 2006.

[13] B. L. and A. D.M., The Thematic Apperception Test, the Children Apperception Test, and the Senior Apperception Technique in Clinical use. Boston: Allyn and Bacon, 1997.

[14] P. M. R., P. V., L. F., X. M., and Y. L., "Stigma and expressed emotion: A study of people with schizophrenia and their family member in China," Br. J. Psychiatry, vol. 181, pp. 488-493, 2002.

[15] P. W. Corrigan, S. B. Morris, P. J. Michaels, J. D. Rafacz, and N. Rusch, "Challenging the public stigma of mental illness: A metaanalysis of outcome studies," Pyschiatric Serv., vol. 63, pp. 963-973, 2012

[16] J. F., K. A. E., J. P. A., C. H., R. B., and P. P., "Mental health literacy: a survey of the public's ability to recognise mental 
disorders and their beliefs about the efffectiveness of treatment," Med. J. Aust., vol. 186, pp. 182-186, 1997.

[17] S. K. McLuckie, W. Y., and W. Y., "Sustained improvements in students' mental health literacy with use of a mental health curriculum in Canadian schools," BMC Psychiatry, vol. 14, 2014.

[18] W. J. and S. D., "Pengaruh pelatihan 'S3hati' terhadap literasi kesehatan jiwa dan keterampilan konseling dasar pada peer counselour,” Skripsi, Universitas Gadjah Mada, Jogjakarta, 2017. 